\title{
New records of flowering plants for the flora of Myanmar collected from southern Shan State
}

\author{
Dae-Hyun KANG, Naing Oo KYAW ${ }^{1}$, Eui-Kwon JUNG, Jae-Seo SHIN, \\ Young-Dong KIM and Homervergel G. ONG* \\ Department of Life Science, Hallym University, Chuncheon 24252, Korea \\ ${ }^{1}$ PPCWS Office, Forest Department (MONREC/MoECAF), Ywangan 06041, Shan State, Myanmar
}

(Received 18 August 2018; Revised 19 September 2018; Accepted 22 September 2018)

\begin{abstract}
Myanmar's plant diversity is expected to be very high given the wide variety of climates and the diverse vegetation and geographical features of the country. Since the publication of Kress et al.'s plant checklist in 2003, new and unrecorded species have been constantly reported by various botanists, but much of Myanmar's flora requires more intensive examinations. We conducted joint floristic surveys of several Ywangan areas, including the Panlaung-Pyadalin Cave Wildlife Sanctuary in southern Shan State of Myanmar. The initial identification of seed plant specimens collected from three short floristic expeditions revealed that 23 species were newly recorded species in Myanmar. More than half of these were found to be geographically notable species, which are known to be endemic to neighboring countries such as China (4 spp.), Thailand (6 spp.), and India (2 spp.). A considerable number of these unrecorded species are distributed in the limestone areas of neighboring countries, reflecting the geological characteristics of the survey area. The results of this study reemphasize the need for intensive and continuous research on the flora of Myanmar for a more comprehensive understanding of the distribution patterns of flowering plants in Southeast Asia.
\end{abstract}

Keywords: endemic species, flora, limestone area, Ywangan, Yunnan

Myanmar is known as a "floristic blank" due to a lack of research on its vegetation despite the fact that it is adjacent to China, India and Thailand, where the rich flora is well known (Tanaka et al., 2018). Studies on plant diversity of Myanmar initiated by the flora publications of Hooker $(1872,1879,1882$, $1885,1890,1894,1897)$ and Kurz $(1877 \mathrm{a}, 1877 \mathrm{~b})$ proceeded very slowly until the presentation of the most recent Myanmar Plant Checklist (Kress et al., 2003). Since then, many new species or newly recorded species in Myanmar have been continuously reported by various researchers around the world (Tanaka and Nagamasu, 2006; Tanaka et al., 2002, 2006a, 2006b, 2007, 2009, 2010a, 2010b, 2010c, 2011, 2015, 2016; Tanaka and Hughes, 2007; Ito et al., 2009; Murata et al., 2010; Yukawa et al., 2010; Tanaka and Hayami, 2011; Gowda et al., 2012; Ormerod, 2011; Tanaka, 2012a, 2012b; Paul, 2013; Wilkin et al., 2013; Peng et al., 2014; Tong and Xia, 2014;
Tan et al., 2015; Cho et al., 2016a, 2016b; Paton et al., 2016; Tanaka and Peng, 2016; Aung et al., 2017; Jin and Kyaw, 2017; Kang et al., 2017a; Liu et al., 2017; Phutthai and Hughes, 2017; Pimenov, 2017; Tanaka and Aung, 2017; Tan et al., 2017; Tseng et al., 2017; Xue et al., 2017; Yang et al., 2017a, 2017b, $2017 \mathrm{c}$ ), reflecting the great interest of botanists in the richness of Myanmar's flora. New species or newly recorded species are continuously being accumulated this year as well (Aung et al., 2018; Chen et al., 2018; Ding et al., 2018; Koyama, 2018; Li et al., 2018; Liu et al., 2018; Ruchisansakun et al., 2018; Tanaka et al., 2018; Wahlsteen, 2018; B. Yang et al., 2018; X. Yang et al., 2018; Yao et al., 2018; Zhou et al., 2018). While eye-opening progress has been made with regard to updating the overall plant list of Myanmar, there are still many more species waiting to be described and placed on the list.

Like all other parts of Myanmar, the flora of Shan State is

\footnotetext{
*Author for correspondence: homervergelong@gmail.com
} 


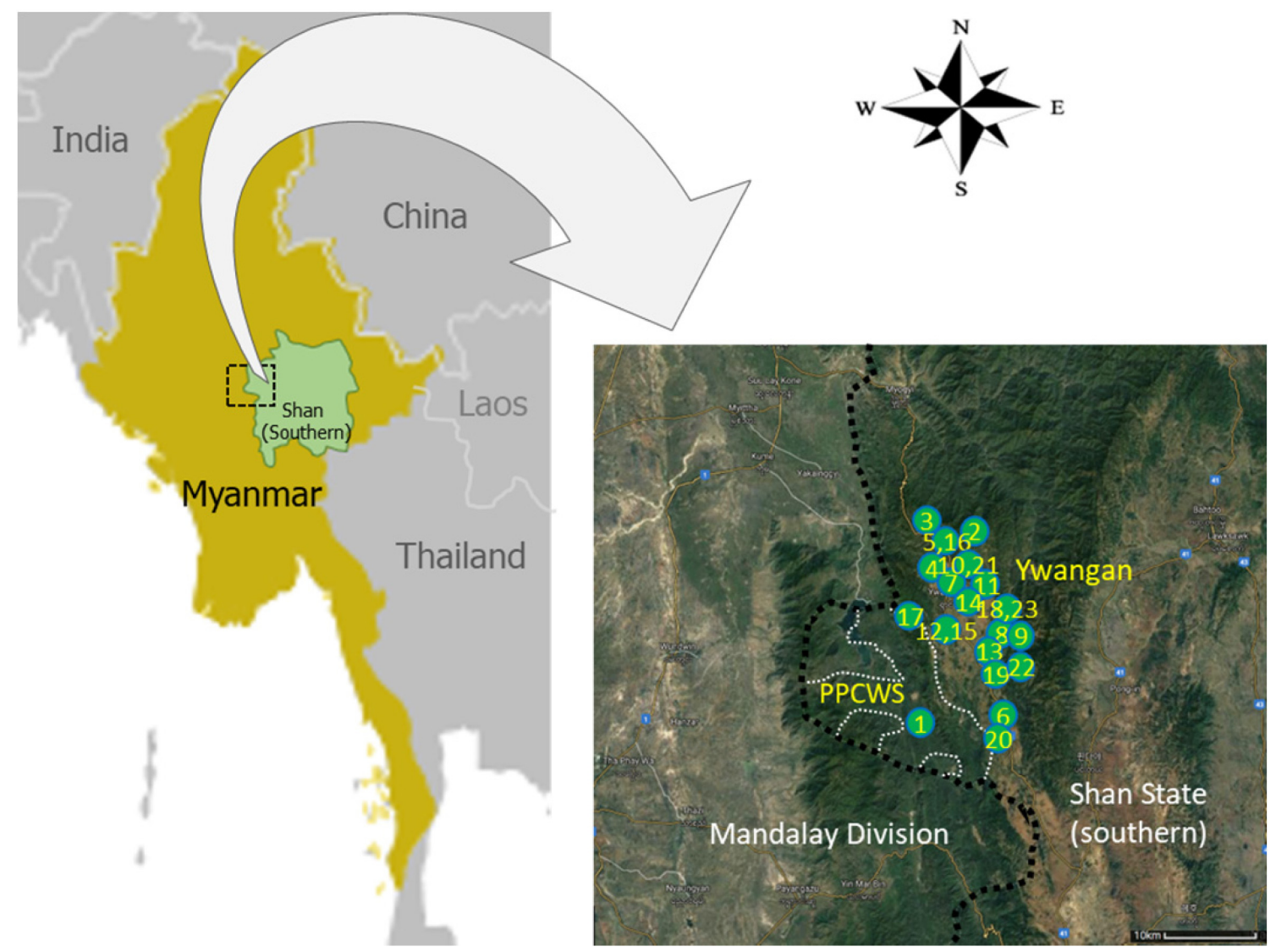

Fig. 1. A map of the surveyed area, showing the distribution of newly recorded Myanmar seed plants. Numbers indicate collected species which appear on the main list of new records. White dotted lines are the boundary of the PPCWS (i.e., the Panlaung-Pyadalin Cave Wildlife Sanctuary).

poorly known. Shan State is a geographical link between China's Yunnan province and regions of northern Thailand. Therefore, there is a high possibility that species distributed in those regions would occur in the state. In addition, limestone areas commonly appearing in southern Shan State have geological features similar to others in many parts of Thailand (Udchachon et al., 2018), implying the possibility of the occurrence of the Thai endemic species distributed in the limestone zone. Ywangan is a major township in the southern Shan State, adjacent to the Panlaung-Pyadalin Cave Wildlife Sanctuary (PPCWS, see Fig. 1), one of the Myanmar's 43 protected areas (Beffasti and Galanti, 2011). The climate in this region is characterized by a long, rainy wet season (May to early December) and a relatively short, cool dry (midDecember to February) and hot dry (March to April) seasons. These areas have elevations in the range of 150-1,555 $\mathrm{m}$ and exhibit various climatic zones from lowland dry areas to highland rainfall areas. Mixed deciduous forests exist in both the highlands and lowlands, and the average annual rainfall in the area is 1,250-2,000 mm (Beffasti and Galanti, 2011).

With the support of National Institute of Biological Resources (NIBR) of the Republic of Korea and MONREC of Myanmar, we conducted three joint floristic surveys of the Ywangan area from February of 2017 to January of 2018. Initial identification of seed plant specimens collected from the three short floristic expeditions revealed that a considerable number of the identified species are geographically notable species, including many new Myanmar records. Here, we report the list of newly recorded species with their original distribution information and brief taxonomic and/or phytogeographic notes.

\section{Materials and Methods}

A total of three floristic surveys were conducted in February of 2017, October of 2017, and January of 2018. The detailed locations of the survey areas are shown in Fig. 1. The collected specimens were identified using the most recent floristic books 
and articles (Wu and Raven, 1994, 2006; Wu et al., 1994, 2005, 2007a, 2007b, 2007c, 2008, 2010; Santisuk and Larsen, 2001, 2002, 2007; Tanaka et al., 2006b; Lee et al., 2014; Fujikawa et al., 2015; Lee et al., 2016; Kang et al., 2017b) as well as via comparisons with the floras of the neighboring countries. Voucher specimens were deposited at the herbarium of Hallym University (HHU) and/or the herbarium of the National Institute of Biological Resources (KB). The plant list of new Myanmar records was arranged in alphabetical order by the family names including the species. Major synonym(s) of each species were also presented along with the accepted name.

\section{Results and Discussion}

Identification of the plant specimens collected in the Ywangan area and the PPCWS revealed that 23 taxa (representing 19 genera in 16 families of flowering plants) were new records in Myanmar. A considerable number of these unrecorded species, including five species of Begonia, are also distributed in the limestone areas of neighboring countries, reflecting the geological characteristics of the survey area (Udchachon et al., 2018). Many of the newly recorded species commonly occur in Yunnan (China) and northern Thailand, but some are also unique in other neighboring countries (see list). Twelve species were found to be geographically notable species, which were also known to be endemic to India (2 spp.), China (4 spp.), and Thailand (6 spp.): Indian endemics - Oreoseris lacei (G. Watt) V. A. Funk \& W. Zheng (Asteraceae), Linum mysorense B. Heyne ex Wa (Linaceae); Chinese endemics - Pimpinella yunnanensis (Franch.) H. Wolff (Apiaceae), Pogostemon chinensis C. Y. Wu \& Y. C. Huang (Lamiaceae), Myrsine faberi (Mez) Pipoly \& C. Chen (Primulaceae), Eriobotrya bengalensis var. angustifolia Cardot (Rosaceae) (Fig. 2); Thai endemics - Hydrocotyle chiangdaoensis Murata (Apiaceae), Rohdea siamensis (Yamashita \& M. N. Tamura) Yamashita \& M. N. Tamura (Asparagaceae), Begonia incerta Craib (Begoniaceae), Begonia soluta Craib (Begoniaceae), Didymocarpus megaphyllus Barnett (Gesneriaceae), Firmiana kerrii (Craib) Kosterm. (Malvaceae) (Fig. 3). Some notable non-endemics are also shown in Fig. 4. The list of all these unrecorded plant taxa is given below.

1. Rungia stolonifera C. B. Clarke, Fl. Br. India 4: 547, 1885 (Acanthaceae) (Fig. 4A).

Justicia stolonifera (C. B. Clarke) B. Hansen, Nord. J. Bot. 9: 210, 1989.

Specimens examined: MYANMAR. Southern Shan State:
Ywangan Township, 21 ${ }^{\circ} 01^{\prime} 53.4^{\prime \prime} \mathrm{N}, 9^{\circ} 24^{\prime} 49.6^{\prime \prime E}$, elev. $804 \mathrm{~m}$, 31 Jan 2018, Kim et al. MM-6543 (HHU).

Type: India, Khasia, Hooker J. D. and Thomson T. s.n. (Type: K), seen as a photo.

Distribution: Bangladesh, China (Yunnan), India (Wu et al., 1994).

Note: This species has the characteristics of a flower of Rungia. However, unlike other species in the genus, which are mostly erect herbs, this species is a vine with a prostrate stem habit. Bracteoles of this species are ovate-lanceolate and are as long as bracts, unlike Rungia chinensis Benth., the most closely allied species (Wu et al., 1994).

2. Hydrocotyle chiangdaoensis Murata, Acta Phytotax. Geobot. 25: 97, 1973 (Apiaceae) (Fig. 3A).

Specimens examined: MYANMAR. Southern Shan State: Ywangan Township, 21 $1^{\circ} 13^{\prime} 50.2^{\prime \prime} \mathrm{N}, \quad 96^{\circ} 31^{\prime} 03.7^{\prime \prime E}$, elev. 1,372 m, 6 Oct 2017, Kim et al. MM-6405 (HHU).

Type: Thailand, Northern Chiang Mai Doi, Chiang Dao, 26 Sep 1971, Murata G. et al. T/15040 (Isotype: L), seen as a photo.

Distribution: Thailand (Shimizu et al., 1984).

Note: This species was first discovered and reported in a limestone area of Thailand. The emergence of this species in this survey area appears to be due to its geological similarity to the type locality in Thailand. The leaf margin (dentation) of the species is unique and easily distinguishable from those of other species in Hydrocotyle (Shimizu et al., 1984).

3. Pimpinella yunnanensis (Franch.) H. Wolff, Pflanzenr. IV 228 (Heft 90): 266, 1927 (Apiaceae) (Fig. 2C).

Carum yunnanense Franch., Bull. Annuel Soc. Philom. Paris VIII, 6: 128, 1894.

Pimpinella pseudocandolleana H. Wolff, Repert. Spec. Nov. Regni Veg. 27 (734-740): 189, 1929.

Specimens examined: MYANMAR. Southern Shan State:

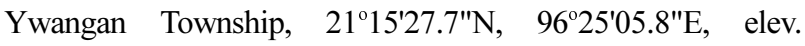
1,383 m, 14 Jan 2017, Kim et al. MM-5995 (HHU, KB).

Type: China, Yunnan, Delavay J. M. 3903 (Isotype: K), seen as a photo.

Distribution: China (Wu et al., 2005).

Note: It is an endemic species distributed in Yunnan (China), and a small number of individuals grow around the forest margins. This species differs from others which closely resemble it, i.e., Pimpinella renifolia $\mathrm{H}$. Wolff, by having cordate-lanceolate or long triangular basal and lowers leaves. This is a very distinguished feature in Pimpinella ( $\mathrm{Wu}$ et al., 2005). 

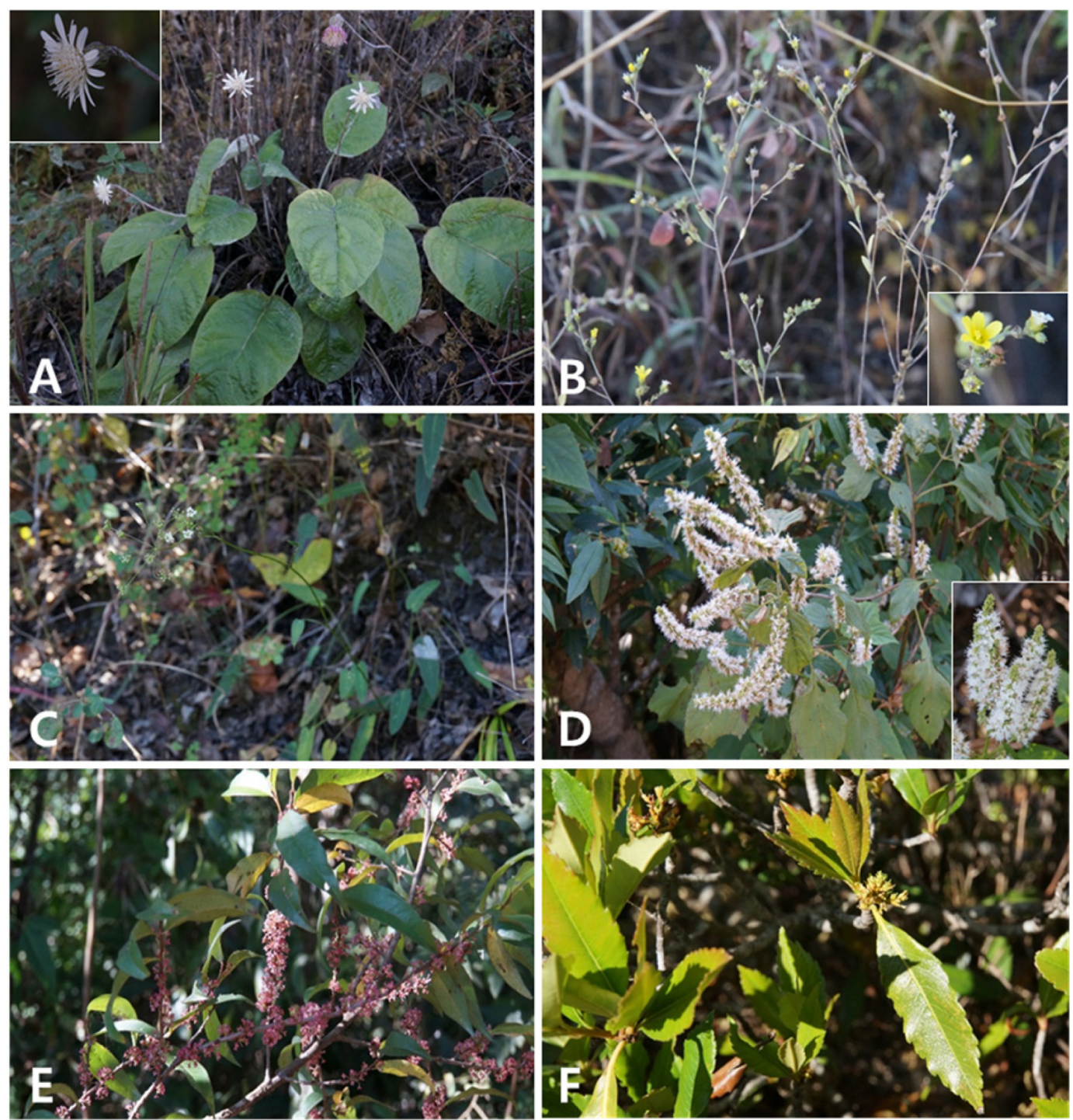

Fig. 2. Newly recorded plant species of Myanmar, formerly known to be endemic to India (A, B) and China (C-F). A. Oreoseris lacei (G. Watt) V. A. Funk \& W. Zheng (Asteraceae). B. Linum mysorense B. Heyne ex Wa (Linaceae). C. Pimpinella yunnanensis (Franch.) H. Wolff (Apiaceae). D. Pogostemon chinensis C. Y. Wu \& Y. C. Huang (Lamiaceae). E. Myrsine faberi (Mez) Pipoly \& C. Chen (Primulaceae). F. Eriobotrya bengalensis var. angustifolia Cardot (Rosaceae).

4. Rohdea siamensis (Yamashita \& M. N. Tamura) Yamashita \& M. N. Tamura, J. Pl. Res. 117: 369, 2004 (Asparagaceae) (Fig. 3B).

Campylandra siamensis Yamashita \& M. N. Tamura, Blumea 46: 183, 2001.

Specimens examined: MYANMAR. Southern Shan State: Ywangan Township, $21^{\circ} 10^{\prime} 09.5^{\prime \prime} \mathrm{N}, \quad 96^{\circ} 26^{\prime} 09.2^{\prime \prime} \mathrm{E}$, elev. 1,234 m, 30 Jan 2018, Kim et al. MM-6495 (HHU).

Type: Information unavailable.

Distribution: Thailand (Yamashita and Tamura, 2001).

Note: This species is characterized by red mature fruit and long white bracts. It is a new genus record in Myanmar.
5. Oreoseris lacei (G. Watt) V. A. Funk \& W. Zheng in Xu et al., Phytokeys 96: 16, 2018 (Asteraceae) (Fig. 2A).

Gerbera lacei G. Watt, Bull. Misc. Inform. Kew 1911: 272. 1911. Uechtritzia lacei (G. Watt) C. Jeffrey, Kew Bull. 21(2): 213. 1967.

Specimens examined: MYANMAR. Southern Shan State: Ywangan Township, 21 $1^{\circ} 14^{\prime} 59.8^{\prime \prime} \mathrm{N}, \quad 96^{\circ} 25^{\prime} 41.8^{\prime \prime} \mathrm{E}$, elev. 1,425 m, 14 Jan 2017, Kim et al. MM-5956 (HHU, KB).

Type: India, Chamba state, 6 Jun 1898, Lace J. H. 1712, (Syntype: E), seen as a photo.

Distribution: N India, S Jammu and Kashmir (Xu et al., 2018). 

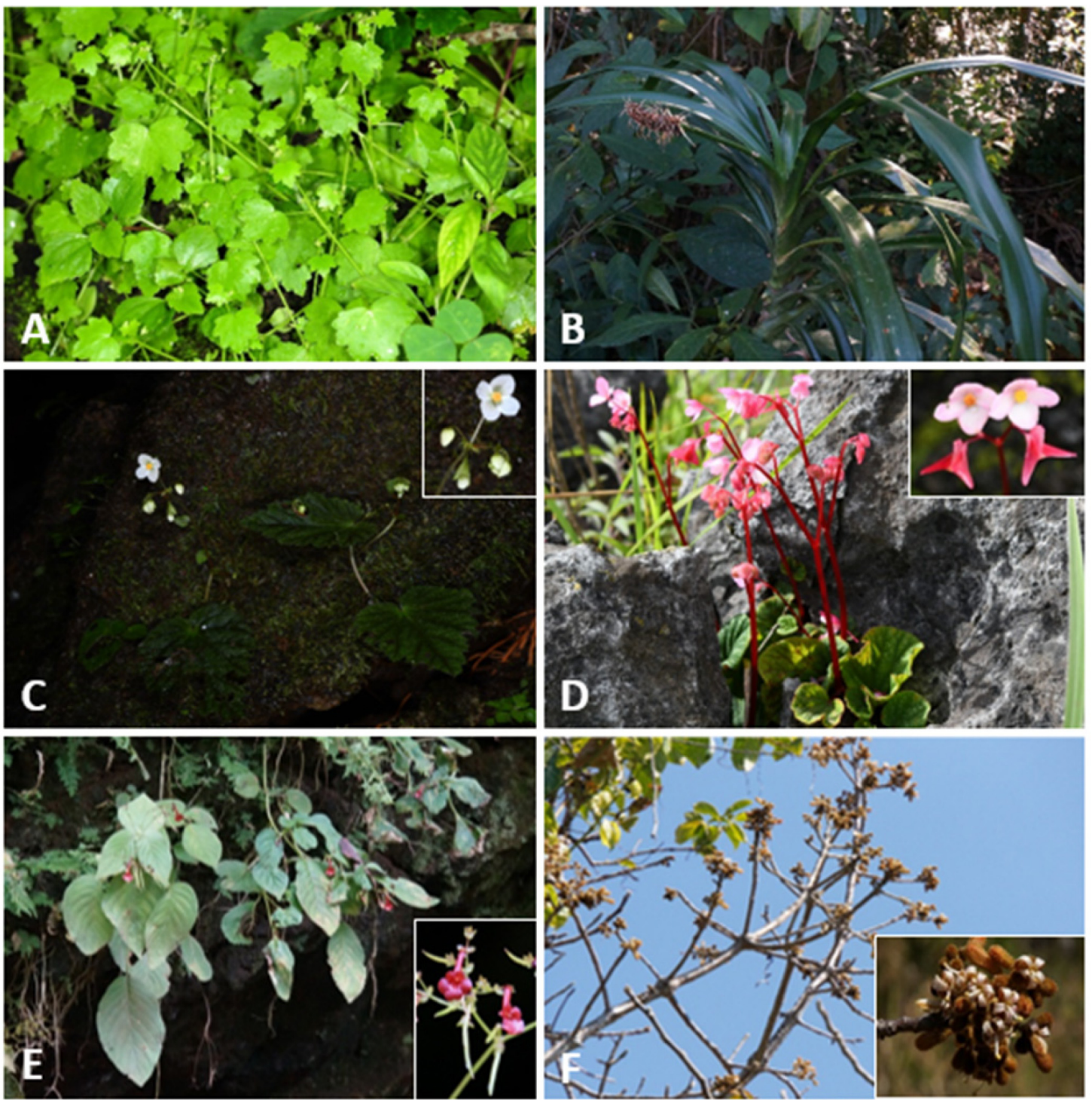

Fig. 3. Newly recorded plant species of Myanmar, formerly known to be endemic to Thailand. A. Hydrocotyle chiangdaoensis Murata (Apiaceae). B. Rohdea siamensis (Yamashita \& M. N. Tamura) Yamashita \& M. N. Tamura (Asparagaceae). C. Begonia incerta Craib (Begoniaceae). D. Begonia soluta Craib. (Begoniaceae). E. Didymocarpus megaphyllus Barnett (Gesneriaceae). F. Firmiana kerrii (Craib) Kosterm. (Malvaceae).

Note: This species was transferred from Gerbera to Uechtritzia and was recently repositioned to Oreoseris. It is noteworthy that the original distribution of this species and this survey area are approximately 2,300 km away (Xu et al., 2018). Future studies of their disjunctive distribution may also be possible. It is a new genus record in Myanmar.

6. Begonia demissa Craib, Bull. Misc. Inform. Kew 1930: 409, 1930 (Begoniaceae) (Fig. 4B).

Specimens examined: MYANMAR. Southern Shan State: Ywangan Township, $21^{\circ} 02^{\prime} 29.3^{\prime \prime} \mathrm{N}, \quad 96^{\circ} 30^{\prime} 48.8^{\prime \prime} \mathrm{E}$, elev.
1,131 m, 5 Oct 2017, Kim et al. MM-6392 (HHU).

Type: Thailand, Baw Re, Kanburi, 21 Jul 1826, Put. 218 (Isotype: BM), seen as a photo.

Distribution: China (Yang et al., 2015), Thailand (Santisuk et al., 2006).

Note: It was originally described from Thailand, but recently it was reported as a new record of Begonia species in China (Yunnan). Considering the geographical location of the Shan state connecting China and Thailand, it is a species that is likely to be distributed in this survey area (Yang et al., 2015). 

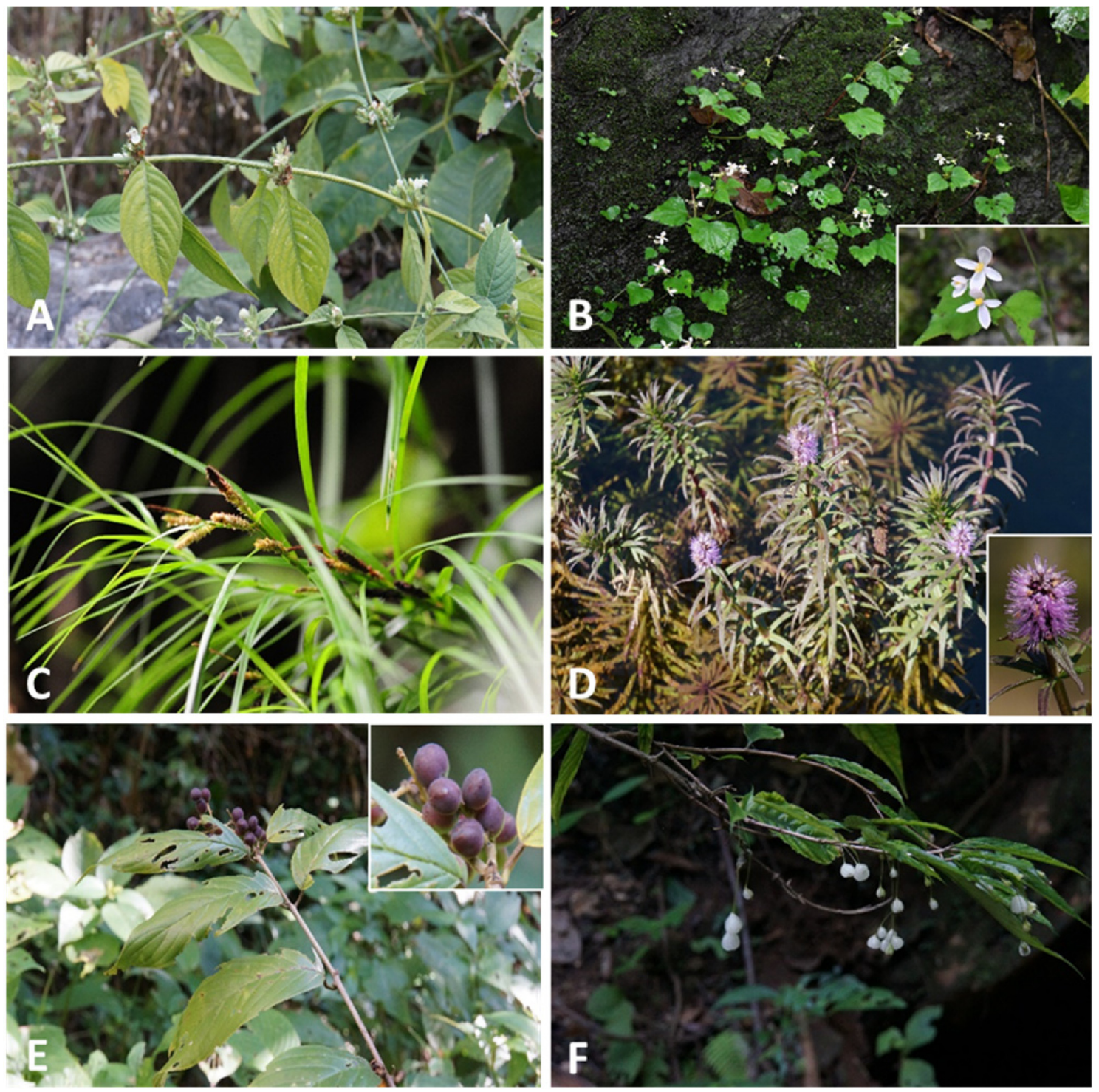

Fig. 4. Newly recorded plant species of Myanmar. A. Rungia stolonifera C. B. Clarke (Acanthaceae). B. Begonia demissa Craib (Begoniaceae). C. Carex maubertiana Boott (Cyperaceae). D. Pogostemon linearis (Benth.) Kuntze (Lamiaceae). E. Sageretia hamosa (Wall.) Brongn. (Rhamnaceae). F. Mycetia cauliflora Reinw. (Rubiaceae).

7. Begonia discreta Craib, Bull. Misc. Inform. Kew 1930: 410, 1930 (Begoniaceae).

Specimens examined: MYANMAR. Southern Shan State: Ywangan Township, 21 $14^{\circ} 24.1^{\prime \prime} \mathrm{N}, \quad 96^{\circ} 26^{\prime} 07.5^{\prime \prime} \mathrm{E}$, elev. 1,464 m, 4 Oct 2017, Kim et al. MM-6317 (HHU).

Type: Thailand, Doi Suthep Chiang Mai, Kerr A. F. G. 3442 (Isotype: TCD), seen as a photo.

Distribution: China (Wu et al., 2007c), Thailand (Santisuk et al., 2006).

Note: It is a species distributed throughout China and Thailand and is likely to be distributed in this survey area for the same reason as Begonia demissa Craib.
8. Begonia incerta Craib, Bull. Misc. Inform. Kew 1911: 57, 1911 (Begoniaceae) (Fig. 3C).

Specimens examined: MYANMAR. Southern Shan State:

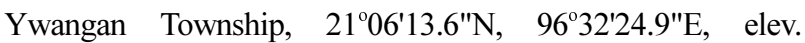
1,358 m, 5 Oct 2017, Kim et al. MM-6350 (HHU).

Type: Thailand, Mej Ping Rapids, 15 Dec 1908, Kerr A. F. G. 508 (Isotype: K), seen as a photo.

Distribution: Thailand (Kerr, 1911).

Note: It is a species endemic to Thailand and is considered to be an indicator species of limestone areas.

9. Begonia siamensis Gagnep., Bull. Mus. Natl. Hist. Nat. 


\section{5: 278, 1919 (Begoniaceae).}

Specimens examined: MYANMAR. Southern Shan State:

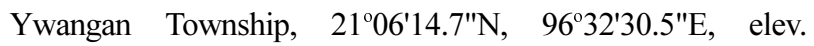
1,346 m, 5 Oct 2017, Kim et al. MM-6355 (HHU).

Type: Thailand, Doi Suthep Chiang Mai, 13 Dec 1904, Hosseus C. C. 238 (Isosyntype: K), seen as a photo.

Distribution: Thailand, Laos (Santisuk et al., 2006).

Note: It was described in Thailand and its distribution was confirmed in Laos. It is considered to be an indicator species of limestone areas.

10. Begonia soluta Craib, Bull. Misc. Inform. Kew 1930: 418, 1930 (Begoniaceae) (Fig. 3D).

Specimens examined: MYANMAR. Southern Shan State: Ywangan Township, $21^{\circ} 15^{\prime} 28.4^{\prime \prime} \mathrm{N}, \quad 96^{\circ} 25^{\prime} 08.8^{\prime \prime} \mathrm{E}$, elev. 1,396 m, 4 Oct 2017, Kim et al. MM-6311 (HHU).

Type: Thailand, Kao Huo mot, Kampeng Pet, 13 Jun 1922, Kerr A. F. G. 6129 (Isotype: BK), seen as a photo.

Distribution: Thailand.

Note: It is an endemic species of Thailand and is considered to be an indicator species of limestone areas.

11. Carex maubertiana Boott, Ill. Gen. Carex 1: 45, pl. 114, 1858 (Cyperaceae) (Fig. 4C).

Carex hebecarpa var. maubertiana (Boott) Franch., Nouv. Arch. Mus. Hist. Nat. III 10: 701898.

Specimens examined: MYANMAR. Southern Shan State:

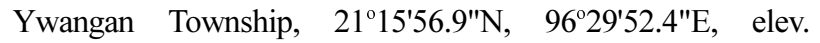
1,286 m, 3 Oct 2017, Kim et al. MM-6238 (HHU).

Type: Vietnam, Cochinchine, Tourane, Jan 1837. Gaudichaud C. s.n. (Isotype: P), seen as a photo.

Distribution: China, India, Nepal, Vietnam (Wu et al., 2010), Cambodia, Laos, Sumatra (Nelmes, 1946).

Note: It is a species that grows widely in neighboring countries and can be expected to be distributed in Myanmar as well. It is characterized by inflorescence borne at the end of the stem, which is easily distinguished from the species of Carex distributed in Southeast Asia (Nelmes, 1946).

12. Pterolobium micranthum Gagnep., Notul. Syst. (Paris) 2: 209, 1912 (Fabaceae).

Specimens examined: MYANMAR. Southern Shan State:

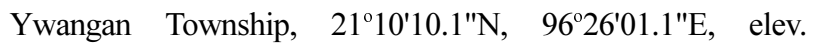
1,235 m, 30 Jan 2018, Kim et al. MM-6520 (HHU).

Type: Thailand, Muong-pran, Aug. 1868, Pierre J. B. L. 187 (Syntype: E), seen as a photo.

Distribution: Thailand, Vietnam.
Note: The deformation of fruit wings is an important trait by which to distinguish species, and the number of leaflets and ratio of the length to width are important diagnostic characters.

13. Didymocarpus megaphyllus Barnett, Nat. Hist. Bull. Siam Soc. 20: 11, 1961 (Gesneriaceae) (Fig. 3E).

Specimens examined: MYANMAR. Southern Shan State:

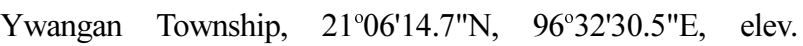
1,346 m, 5 Oct 2017, Kim et al. MM-6359 (HHU).

Type: Thailand, Ban Kawp, Surat, 8 Aug 1927, Kerr A. F. G. 13215 (Holotype: K), seen as a photo.

Distribution: Thailand (Nangngam and Maxwell, 2013).

Note: It is an endemic species distributed in southern Thailand. This species has large leaves and dark red or crimsonred flower, which distinguish it well from other species in Didymocarpus (Nangngam and Maxwell, 2013).

14. Pogostemon chinensis C. Y. Wu \& Y. C. Huang, Fl. Yunnanica 1: 742, 1977 (Lamiaceae) (Fig. 2D).

Specimens examined: MYANMAR. Southern Shan State: Ywangan Township, 21 $11^{\circ} 09.0^{\prime \prime} \mathrm{N}, \quad 96^{\circ} 28^{\prime} 27.1^{\prime \prime E}$, elev. 1,641 m, 1 Feb 2018, Kim et al. MM-6630 (HHU).

Type: China, Yunnan Prov., Yangbi yizu zizhixian, Liu Shene s.n. (Isotype: PE), seen as a photo.

Distribution: China (Yao et al., 2015).

Note: Spikes are longer than $5 \mathrm{~cm}$ compared to relatives. The calyx tube is subtubular and glandular in the flower, and the teeth of the calyx are narrowly triangular and subequal (Yao et al., 2015).

15. Pogostemon linearis (Benth.) Kuntze, Revis. Gen. Pl. 2: 530, 1891. (Lamiaceae) (Fig. 4D).

Dysophylla linearis Benth., Prodr. 12: 157, 1848; Anuragia linearis (Benth.) Raizada, Suppl. Duthie's Fl. Upper Gangetic Plain 218, 1976; Eusteralis linearis (Benth.) Panigrahi, Phytologia 32: 476, 1976.

Specimens examined: MYANMAR. Southern Shan State: Ywangan Township, $21^{\circ} 10^{\prime} 09.5^{\prime \prime} \mathrm{N}, \quad 96^{\circ} 26^{\prime} 09.2^{\prime \prime} \mathrm{E}$, elev. 1,234 m, 30 Jan 2018, Kim et al. MM-6490 (HHU).

Type: India, Pandua Dekelua, Wallich N. 1540 (Type: HBG), seen as a photo.

Distribution: China, India (Yao et al., 2015).

Note: Stems of this species are pubescent, whereas those of related species are strigose. The leaves are verticillate and sessile (Yao et al., 2015).

16. Linum mysorense B. Heyne ex Wa, Numer. List 1507, 1829 (Linaceae) (Fig. 2B). 
Specimens examined: MYANMAR. Southern Shan State: Ywangan Township, 21 $14^{\circ} 59.8^{\prime \prime} \mathrm{N}, \quad 96^{\circ} 25^{\prime} 41.8^{\prime \prime} \mathrm{E}$, elev. 1,425 m, 14 Jan 2017, Kim et al. MM-5945 (HHU, KB).

Type: Information unavailable.

Distribution: India (Gill, 1987).

17. Firmiana kerrii (Craib) Kosterm., Reinwardtia 5: 389, 1961 (Malvaceae) (Fig. 3F).

Sterculia kerrii Craib, Kew Bull. 1915: 424, 1915; in Fl. Siam. Enum. 1: 167, Fig. 67, 1925.

Specimens examined: MYANMAR. Southern Shan State: Ywangan Township, $21^{\circ} 08^{\prime} 30.6^{\prime \prime} \mathrm{N}, 96^{\circ} 24^{\prime} 17.2^{\prime \prime}$ E, elev. 1,426 m, 1 Feb 2018, Kim et al. MM-6614 (HHU).

Type: Thailand, Dio Chung Dao, 28 Jan 1913, Kerr A. F. G. 2866 (Type: BM), seen as a photo.

Distribution: Thailand (Santisuk and Larsen, 2001).

Note: It is a species endemic to Thailand and is rarely distributed in limestone areas, which reflects the geological characteristics of the survey area (Santisuk and Larsen, 2001).

18. Stephania japonica var. timoriensis (DC.) Forman, Kew Bull. 11: 49, 1956. (Menispermaceae)

Cocculus japonicus var. timoriensis DC., Prodr. 1: 96, 1824.

Specimens examined: MYANMAR. Southern Shan State: Ywangan Township, $21^{\circ} 15^{\prime} 45.8^{\prime \prime} \mathrm{N}, 96^{\circ} 29^{\prime} 43.8^{\prime \prime} \mathrm{E}$, elev. 1,313 m, 12 Jan 2017, Kim et al. MM-5772 (HHU, KB); Ywangan

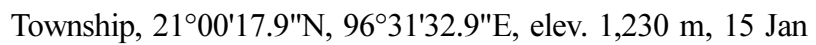
2017, Kim et al. MM-6090 (HHU, KB).

Type: Indonesia, Timor, anonymous s.n. (Type: GDC), seen as a photo.

Distribution: Bangladesh, China, Indonesia; Australia, Pacific Islands (Wu et al., 2008).

Note: It is widely distributed in neighboring countries and is highly likely to occur in Myanmar (Wu et al., 2008).

19. Myrsine faberi (Mez) Pipoly \& C. Chen, Novon 5: 360, 1995 (Primulaceae) (Fig. 2E).

Rapanea faberi Mez, Pflanzenr. IV 236 (Heft 9): 358, 1902.

Specimens examined: MYANMAR. Southern Shan State:

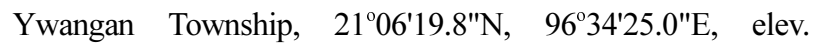
1,929 m, 13 Jan 2017, Kim et al. MM-5905 (HHU, KB).

Type: China, Mengtze, mountains to south, 6,000 feet, $A$. Henry, $9173 \mathrm{~A}$ (Isosyntype: A), seen as a photo.

Distribution: China (Yunnan) (Wu and Raven, 1996).

Note: The leaves of this species are very narrowly lanceolate or oblanceolate and the leaf margin is entire. The calyx is papery and the lobes are ovate (Wu and Raven, 1996).
20. Sageretia hamosa (Wall.) Brongn., Mém. Fam. Rhamnées 53, 1826 (Rhamnaceae) (Fig. 4E).

Ziziphus hamosa Wall., Fl. Ind., ed. 1820 2: 369-370, 1824.

Rhamnus affinis Blume, Bijdr. Fl. Ned. Ind. 17: 1140, Oct 1826-Nov 1827; Sageretia affinis (Blume) G. Don, Gen. Hist. 2: $29,1832$.

Specimens examined: MYANMAR. Southern Shan State: Ywangan Township, 2059'57.9"N, 96 34'09.3"E, elev. 1,285 m, 3 Feb 2018, Kim et al. MM-6699 (HHU).

Type: Nepal, Napalia, Wallich N. \#4253-a (Isotype: P), seen as a photo.

Distribution: China, India, Nepal, Philippines, Sri Lanka, Vietnam (Wu et al., 2007b).

Note: Although the distribution area of the species is very wide, ranging from the Philippines to Nepal, it is considered to be a rare species. It is an indicator species of limestone areas and is also found in the limestone areas of many neighboring countries. Currently, several new species are described from Sageretia in limestone areas (Wu et al., 2007b).

21. Eriobotrya bengalensis var. angustifolia Cardot, Notul. Syst. (Paris) 3: 371, 1918 (Rosaceae) (Fig. 2F).

Eriobotrya bengalensis f. angustifolia (Cardot) J. E. Vidal, Adansonia n.s. 5: 569, 1965.

Specimens examined: MYANMAR. Southern Shan State:

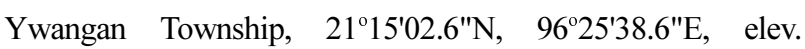
1,403 m, 14 Jan 2017, Kim et al. MM-5965 (HHU, KB).

Type: China, Yunnan, 29 Mar 1907, Ducloux F. 4719 (Holotype: P), seen as a photo.

Distribution: China (SE Yunnan) (Wu et al., 2007a).

Note: It is a Chinese endemic species which grows in hilly areas in the survey area. The species are often shrubby and resemble an oak species. The species is characterized by having an incised-serrate leaf margin and tomentose peduncle and pedicels. The leaf shape is very similar to the closely allied taxon, but the texture is softer (Wu et al., 2007a).

22. Mycetia cauliflora Reinw., Syll. Pl. Nov. 2: 9, 1825 (Rubiaceae) (Fig. 4F).; Adenosacme cauliflora. (Reinw.) Miq., Fl. Ind. Bat. 2: 215, 1857.

Bertiera lateriflora Blume, Bijdr. 988, 1826; Mycetia lateriflora (Blume) Korth., Ne derl. Kruidk. Arch. 2: 118, 1851. Bertiera chrysantha Hassk., Retzia 1: 30, 1855.

Mycetia cauliflora var. macrocalyx Hassk., Retzia 1: 33, 1855. Bertiera macrocalyx Hassk., Ned. Kruidk. Arch. 4: 7, 1856. Mycetia javanica Hook. f., Fl. Brit. India 3: 95, 1880.

Adenosacme scortechinii King \& Gamble, J. Asiat. Soc. Bengal, Pt. 2, Nat. Hist. 72: 197, 1903; Mycetia scortechinii 
(King \& Gamble) Ridl., Fl. Malay Penins. 2: 63, 1923.

Specimens examined: MYANMAR. Southern Shan State:

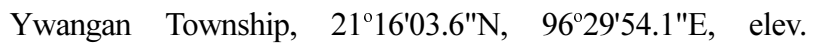
1,155 m, 12 Jan 2017, Kim et al. MM-5844 (HHU, KB);

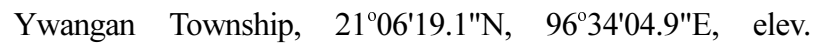
1,857 m, 13 Jan 2017, Kim et al. MM-5900 (HHU, KB); Ywangan Township, $21^{\circ} 16^{\prime} 03.5^{\prime \prime} \mathrm{N}, \quad 96^{\circ} 29^{\prime} 53.3^{\prime \prime E}$, elev. 1,175 m, 3 Oct 2017, Kim et al. MM-6228 (HHU).

Type: Philippines, Mindanao, Cotabato, Apo, Todaya (Apo Mt.), District of Davao, Elmer. A.D.E. 10504 (Isotype: U), seen as a photo.

Distribution: Indonesia, Thailand, Malaysia, Philippines (Yan et al., 2016).

Note: It grows in humid rocky areas and is easily distinguishable from sympatric plant species due to its white fruit on long pedicels. One of the diagnostic characters of the species is the stipules, which is ovate-lanceolate, acuminate or acute at the apex, subscarious. The leaves are glabrous and larger (3.5-9 cm wide) than closely allied species (Yan et al., 2016).

23. Rubia siamensis Craib, Bull. Misc. Inform. Kew 1911: 397, 1911 (Rubiaceae).

Specimens examined: MYANMAR. Southern Shan State: Ywangan Township, $21^{\circ} 15^{\prime} 45.8^{\prime \prime} \mathrm{N}, \quad 96^{\circ} 29^{\prime} 43.8^{\prime \prime} \mathrm{E}$, elev. 1,313 m, 12 Jan 2017, Kim et al. MM-5790 (HHU, KB).

Type: Thailand, Dam Sutip, 14 May 1911, Kerr A. F. G. 1832 (Type: K), seen as a photo.

Distribution: China (SW Yunnan), Thailand (Wu et al., 1994b).

Note: It was first described in Thailand and confirmed to be distributed in China as well. This species is characterized by distinct single mid-vein, pinnate lateral veins and triangular small stipules. The dark green color of the dried leaf is also a distinguishing feature of the species (Wu et al., 1994b). The occurrence of this species can be expected in the survey area, which is connected to two current distribution areas, SW Yunnan and Thailand.

It should be emphasized that a considerable number of newly recorded plant species were collected within the relatively short periods of the expeditions. Considering that most of the examined sites are places easily accessible by car and on foot, the number of new records appears to be relatively high. In addition, many of the newly recorded species are commonly distributed in Yunnan (China) and northern Thailand, filling in the floristic discontinuity between the two areas. The results of this study reemphasize the need for intensive and continuous research on the flora of Myanmar for a more comprehensive understanding of the distribution patterns of flowering plants in Southeast Asia. Furthermore, there are many more species in Myanmar waiting to be described, as much of the country is still untouched and has scarcely been accessed by botanists.

\section{Acknowledgments}

This work was supported by grants from the National Institute of Biological Resources (NIBR), the Ministry of Environment (MOE) of the Republic of Korea (NIBR2018 04201). Our gratitude extends to the Ministry of Natural Resources and Environmental Conservation (MONREC) of Myanmar for the continuous guidance and support for this project.

\section{Conflict of Interest}

The authors declare that there are no conflicts of interests.

\section{Literature Cited}

Aung, Y. L., X. Jin and A. Schuiteman. 2017. Coelogyne putaoensis (Orchidaceae), a new species from Myanmar. PhytoKeys 82: $27-34$.

Aung, Y. L., A. T. Mu and X. Jin. 2018. Odontochilus putaoensis (Cranichideae, Orchidaceae), a new species from Myanmar. PhytoKeys 103: 19-26.

Beffasti, L. and V. Galanti. 2011. Myanmar Protected Areas: Context, Current Status and Challenges. Ancora Libri Press, Milan. Pp. 72-73.

Chen, W.-H., X.-H. Jin and Y.-M. Shui. 2018. Rediscovery and amended descriptions of Begonia kingdon-wardii (Begoniaceae) from North Myanmar. PhytoKeys 94: 59-64.

Cho, S.-H., P. Chhang and Y.-D. Kim. 2016a. A Checklist for the Seed Plants of Cambodia. National Institute of Biological Resources, Incheon, $272 \mathrm{pp}$.

Cho, S.-H., J.-H. Lee, D.-H. Kang, B.-Y. Kim, A. Trias-Blasi, K.M. Htwe and Y.-D. Kim. 2016b. Cissus erecta (Vitaceae), a new non-viny herbaceous species from Mt. Popa, Myanmar. Phytotaxa 260: 291-295.

Ding, H.-B., Y. Bin, S.-S. Zhou, R. Li, M. B. Maw, W. M. Kyaw and Y.-H. Tan. 2018. Hedychium putaoense (Zingiberaceae), a new species from Putao, Kachin State, Northern Myanmar. PhytoKeys 94: 51-57.

Fujikawa, K., P. Srisanga, S. Watthana, L.-S. Mane, L. Shine, T.M. Soe and S.-G. Ngai. 2015. 100 Wild Flowers of Natma Taung: Natma Taung National Park, Chin State, Myanmar. The Kochi Prefectural Makino Botanical Garden, Kochi, 76 
$\mathrm{pp}$.

Gill, K. S. 1987. Linseed. Publications and Information Division Indian Council of Agricultural Research Krishi Anusandhan Bhavan, Pusa, New Delhi, 387 pp.

Gowda, V., W. J. Kress and T. Htun. 2012. Two new species of Gingers (Zingiberaceae) from Myanmar. PhytoKeys 13: 5-14.

Hooker, J. D. 1872. Flora of British India. Vol. 1. Ranunculaceae to Polygalaceae. L. Reeve \& Co., London, 740 pp.

Hooker, J. D. 1879. Flora of British India. Vol. 2. Sabiaceae to Cornaceae. L. Reeve \& Co., London, 792 pp.

Hooker, J. D. 1882. Flora of British India Vol. 3 Caprifoliaceae to Apocynaceae. L. Reeve \& Co., London, 712 pp.

Hooker, J. D. 1885. Flora of British India Vol. 4. Asclepiadaceae to Amaranthaceae. L. Reeve \& Co., London, 630 pp.

Hooker, J. D. 1890. Flora of British India. Vol. 5. Chenopodiaceae to Orchidaceae. L. Reeve \& Co., London, 250 pp.

Hooker, J. D. 1894. Flora of British India. Vol. 6. Orchidaceae to Cyperaceae. L. Reeve \& Co., London, 792 pp.

Hooker, J. D. 1897. Flora of British India. Vol. 7. Cyperaceae, Gramineae and General Index. L. Reeve \& Co., London, 842 pp.

Ito, Y., N. Tanaka, T. Ohi-Toma and J. Murata. 2009. New or noteworthy plant collection from Myanmar (3): Cardesia parnassifolia, Nechamandra alternifolia, Potamogeton maackianus and P. octandrus. Journal of Japanese Botany 84: 321-329.

Jin, X.-H. and M. Kyaw. 2017. Gastrodia putaoensis sp. nov. (Orchidaceae, Epidendroideae) from North Myanmar. Nordic Journal of Botany 35: 730-732.

Kang, D.-H., J.-H. Lee, H. G. Ong, S. M. Ling and Y-D. Kim. 2017a. Seed Plants of Natma Taung National Park, Myanmar. National Institute of Biological Resources (NIBR), Incheon, 632 pp.

Kang, D.-H., S. M. Ling, Y.-D. Kim and H. G. Ong. 2017b. New records of flowering plants of the flora of Myanmar collected from Natma Taung National Park (Chin State). Korean Journal of Plant Taxonomy 47: 199-206.

Kerr, A. F. G. 1911. Contributions to the flora of Siam-I. Sketch of the vegetation of Chiengmai. Bulletin of Miscellaneous Information (Royal Botanic Gardens, Kew) 1911: 1-60.

Koyama, T. 2018. Notes on Cyperaceae from Myanmar. Part 2. Taiwania 63: 1-6.

Kress, W. J., R. A. De Filipps, E. Farr and D. Y. Y. Kyi. 2003. A checklist of the trees, shrubs, herbs, and climbers of Myanmar. Contributions from the Unites States National Herbarium, 45: 1-590.

Kurz, S. 1877a. Forest Flora of British Burma. Vol. 1. Ranunculaceae to Cornaceae. Office of the Superintendent of Government Printing, Calcutta, 549 pp.
Kurz, S. 1877b. Forest Flora of British Burma. Vol. 2. Caprifoliaceae to Filices. Office of the Superintendent of Government Printing, Calcutta, 613 pp.

Lee, W.-S., J.-I. Choe, H.-K. Kim, J.-H. Jung, J.-H. Jeon, J.-S. Kim, J.-U. Kim, M.-S. Jeong, J.-K. Park, E.-Y. Choi, W.-N. Zarchi, S.-Y. Kim, J.-B. Choi, D.-I. Cho, M.-H. Kim, D.-H. Kang, S.-H. Cho, J.-H. Lee, H.-G. Ong, Y.-I. Kim, B.-Y. Kim, H.-S. Park, S.-M. Ling, Y.-D. Kim, M.-O. Moon, S.-J. Pak, N.-R. Yoon, T.-Y. New and B.-Y. Sun. 2016. Biodiversity of Natma Taung National Park, Myanmar. National Institute of Biological Resources (NIBR), Incheon, 288 pp.

Lee, W.-S., N. Z. Htun, N. M. Lay, J.-I. Choe, J.-H. Jung, J.-K. Park, J.-Y. Park, W. N. Zarchi, E.-Y. Choi, I.-J. Choi, Y.-K. Oh, J.-L. Lim, J.-B. Choi, Y.-D. Kim and S.-H. Cho. 2014. Biodiversity of Mt. Popa, Myanmar. National Institute of Biological Resources, Incheon, 224 pp.

Li, J.-W., Y.-H. Tan, X.-L. Wang, C.-W. Wang and X.-H. Jin. 2018. Begonia medogensis, a new species of Begoniaceae from Western China and Northern Myanmar. PhytoKeys 103: 13-18.

Liu, Q., S.-S. Zhou, X.-H. Jin, B. Pan, K. W. Maung, M. Zyaw, R. Li, R.-C. Quan and Y.-H. Tan. 2018. Dendrobium naungmungense (Orchidaceae, Dendrobieae), a new species from Kachin State, Myanmar. PhytoKeys 94: 31-38.

Liu, Q., S.-S. Zhou, R. Li, M.-X. Zhang, M. Zyaw, S. Lone and R.-C. Quan. 2017. Bulbophyllum putaoensis (Orchidaceae: Epidendroideae; Malaxideae), a new species from Kachin State, Myanmar. Phytotaxa 305: 57-60.

Murata, J., T. Ohi-Toma and N. Tanaka. 2010. New or noteworthy plant collections from Myanmar (4): Typhonium cordifolium and two new species, T. neogracile and T. praecox (Araceae). Journal of Japanese Botany 85: 1-7.

Nangngam, P. and J. F. Maxwell. 2013. Didymocarpus (Gesneriaceae) in Thailand. Gardens' Bulletin Singapore 65: 185-225.

Nelmes, E. 1946. A key to the Carices of Malaysia and Polynesia. Kew Bulletin 1: 5-29.

Ormerod, P. 2011. Orchidaceous additions to the flora of China. Taiwania 56: 42-49.

Paton, A., S. Suddee and B. Bongcheewin. 2016. Two new species of Scutellaria (Lamiaceae) from Thailand and Burma. Kew Bulletin 71: 3.

Paul, T. K. 2013. Pterospermum truncatolobatum Gagnepain [Sterculiaceae]: an addition to the flora of Myanmar. Pleione 7: 571-573.

Peng, C.-I., H. Wang, Y. Kono and H.-A. Yang. 2014. Begonia wui-senioris (sect. Platycentrum, Begoniaceae), a new species from Myanmar. Botanical Studies 55: 13-16.

Phutthai, T. and M. Hughes. 2017. A new species of Begonia section Parvibegonia (Begoniaceae) from Thailand and Myan- 
mar. Blumea 62: 26-28.

Pimenov, M. G. 2017. Novelties in Myanmar Umbelliferae: a new species of Oenanthe L. and two new floristic records. Botanica Pacifica 6: 43-47.

Ruchisansakun, S., P. Suksathan, T. van der Niet, E. F. Smets, S. Lwin and S. B. Janssens. 2018. Three new species of Impatiens (Balsaminaceae) from Myanmar. Phytotaxa 338: 63-74.

Santisuk. T., K. Chayamarit, R. Pooma and S. Suddee. 2006. Thailand Red Data Plants. Office of Natural Resources and Environmental Policy and Planning (ONEP), Bangkok, 254 pp.

Santisuk, T. and K. Larsen. 2001. Flora of Thailand. Vol. 7. Part 3. Spermatophyte: Alismataceae to Steruliaceae. Royal Forest Department, Bangkok, 654 pp.

Santisuk, T. and K. Larsen. 2002. Flora of Thailand. Vol. 7. Part 4. Spermatophyte: Buddlejaceae to Viscaceae. Royal Forest Department, Bangkok, 285 pp.

Santisuk, T. and K. Larsen. 2007. Flora of Thailand. Vol. 8. Part 2. Spermatophyte: Euphorbiaceae. Royal Forest Department, Bangkok, 618 pp.

Shimizu, T., F. Konta, H. Koyama and M. Shimizu. 1984. Contributions to the flora of Southeast Asia VII. Taxonomy and phytogeography of some temperate species in Thailand (3). Acta Phytotaxonomica et Geobotanica 35: 37-43.

Tan, Y., D. Li, Y. Chen and B. Li. 2017. Premna bhamoensis (Lamiaceae, Premnoideae), a new species from Kachin State, northeastern Myanmar. PhytoKeys 83: 93-101.

Tan, Y.-H., B. Yang, J.-W. Li, S.-S. Zhou, S. Lone, K. K. Khaing, R. Li, J.-P. Huang and H. Sun. 2015. Acranthera burmanica, a new species of Rubiaceae from Kachin State, Myanmar. Phytotaxa 238: 92-96.

Tanaka, N. 2005. Plant inventory research: contributions to the flora of Myanmar. Acta Phytotaxonomica et Geobotanica 56: 21-26.

Tanaka, N. 2010. Plant inventory research in Myanmar. Bunrui 10: 139-149. (in Japanese).

Tanaka, N. 2012a. Studies of Zingiberaceae in Myanmar I: Zingiberidae, newly recorded from Myanmar. Makinoa New Series 10: 153-157.

Tanaka, N. 2012b. Studies of Zingiberaceae in Myanmar II: Zingiber popaense, a new species from Myanmar. Makinoa New Series 10: 159-163.

Tanaka, N. and M. M. Aung. 2017. A new species of Zingiber (sect. Dymczewiczia: Zingiberaceae) from northwestern Myanmar. Phytotaxa 316: 195-199.

Tanaka, N. and Y. Hayami. 2011. Begonia kachinensis (Begoniaceae, sect. Sphenanthera), a new species from Myanmar. Acta Phytotaxonomica et Geobotanica 61: 151-154.

Tanaka, N. and M. Hughes. 2007. Begonia (sect. Sphenanthera) hayamiana (Begoniaceae), a new species from northern
Myanmar. Acta Phytotaxonomica et Geobotanica 58: 83-86. Tanaka, N., Y. Kadota and J. Murata. 2010a. New or noteworthy plant collection from Myanmar (6): Ranunculaceae of Mt. Victoria, Chin State, Myanmar. Journal of Japanese Botany 85: 199-212.

Tanaka, N., S. Kobayashi, T. Ohi-Toma and J. Murata. 2006a. New or noteworthy plant collections from Myanmar (1) Hydrobryum japonicum, Balanophora subcupularis, Rhopalocnemis phalloides and Sonerila laeta. Journal of Japanese Botany 81: 324-331.

Tanaka, N., T. Koyama and J. Murata. 2006b. The flowering plants of Mt. Popa, central Myanmar. Bulletin of the Makino Botanical Garden (5): 1-102.

Tanaka, N. and H. Nagamasu. 2006. A new record of Gmelina tomentosa Fletcher (Verbenaceae) from Myanmar. Acta Phytotaxonomica et Geobotanica 57: 233-236.

Tanaka, N., T. Ohi-Toma and J. Murata. 2009. A taxonomic study of Rosa clinophylla var. glabra (Rosaceae), newly recorded from Myanmar, based on morphological and molecular data. Journal of Japanese Botany 84: 27-32.

Tanaka, N., T. Ohi-Toma and J. Murata. 2010b. A new species from Argostemma (Rubiaceae) from Mount Victoria, Myanmar. Blumea 55: 65-67.

Tanaka, N., T. Ohi-Toma, H. Murata, M. M. Aung and J. Murata. 2016. New or noteworthy plant collections from Myanmar (9): Agapetes (Ericaceae) from Northwestern Myanmar. Journal of Japanese Botany 91: 99-111.

Tanaka, N. and C.-I. Peng. 2016. Begonia togashii (Begoniaceae: sect. Platycentrum), a new species from central Myanmar. Acta Phytotaxonomica et Geobotanica 67: 191-197.

Tanaka, N., T. Sugawara, M. M. Aung and J. Murata. 2015. Impatiens kingdon-wardii (Balsaminaceae), a new species from Mt. Victoria (Natma Taung), Myanmar. Phytotaxa 234: 90-94.

Tanaka, N., S. Tagane, A. Naiki, M. M. Aung, N. Tanaka, S. Dey, J. Mood and J. Murata. 2018. Contributions to the Flora of Myanmar I: nine taxa of monocots newly recorded from Myanmar. Bulletin of the National Museum of Nature and Science, Series B (Botany) Tokyo 44: 31-39.

Tanaka, N., N. Tanaka, T. Ohi-Toma and J. Murata. 2007. New or noteworthy plant collections from Myanmar (2) Aponogeton lakhonensis, Cryptocoryne cruddasiana, C. crispatula var. balansae and Stichoneuron memranaceum. Journal of Japanese Botany 82: 266-273.

Tanaka, N., T. Yukawa, K. M. Htwe, T. Koyama and J. Murata. 2011. New or noteworthy plant collections from Myanmar (7): fourteen additional species of Orchidaceae. Acta Phytotaxonomica et Geobotanica 61: 161-165.

Tanaka, N., T. Yukawa, K. M. Htwe and J. Murata. 2002. An orchid checklist of Mt. Popa, central Myanmar. Bulletin of the National 
Museum of Nature and Science, Series B (Botany), Tokyo 41: 69-89.

Tanaka, N., T. Yukawa and J. Murata. 2010c. New or noteworthy plant collection from Myanmar (5): Dendrobium koyamae, a new species in sect. Formosa (Orchidaceae). Acta Phytotaxonomica et Geobotanica 60: 171-174.

Tong, Y. H. and N. H. Xia. 2014. New taxa of Agapetes (Ericaceae) from Myanmar. Phytotaxa 184: 39-45.

Tseng, Y.-H., Y.-D. Kim, C.-I. Peng, K. M. Htwe, S.-H. Cho, Y. Kono and K.-F. Chung. 2017. Begonia myanmarica (Begoniaceae), a new species from Myanmar, and molecular phylogenetics of Begonia sect. Monopteron. Botanical Studies 58: 21.

Udchachon, M., P. Charusiri, H. Thassanapak and C. Burrett. 2018. A new section of Lower Palaeozoic rocks in Kayin State (Southeast Myanmar). Proceedings of the Geologists' Association 129: 215-226.

Wahlsteen, E. 2018. Begonia mariachristinae (Begoniaceae), a new species from northern Myanmar. Edinburgh Journal of Botany 75: 161-166.

Wilkin, P., P. Suksathan, K. Keeratikiat, P. van Welzen and J. Wiland-Szymanska. 2013. A new species from Thailand and Burma, Dracaena kaweesakii Wilkin \& Suksathan (Asparagaceae subfamily Nolinoideae). PhytoKeys 26: 101-112.

Wu, Z. Y. and P. H. Raven. 1994. Flora of China. Vol. 17. Verbenaceae to Solanaceae. Science Press, Beijing and Missouri Botanical Garden Press, St. Louis, MO, 342 pp.

Wu, Z. Y. and P. H. Raven. 1996. Flora of China. Vol. 15. Myrsinaceae to Loganiaceae. Science Press, Beijing and Missouri Botanical Garden Press, St. Louis, MO, 387 pp.

Wu, Z. Y., P. H. Raven and D. Y. Hong. 1994. Flora of China. Vol. 19. Cucurbitaceae through Valerianaceae with Annonaceae and Berberidaceae. Science Press, Beijing and Missouri Botanical Garden Press, St. Louis, MO, 884 pp.

Wu, Z. Y., P. H. Raven and D. Y. Hong. 2005. Flora of China. Vol. 14. Apiaceae to Ericaceae. Science Press, Beijing and Missouri Botanical Garden Press, St. Louis, MO, 292 pp.

Wu, Z. Y., P. H. Raven and D. Y. Hong. 2007a. Flora of China. Vol. 9. Pittosporaceae to Connaraceae. Science Press, Beijing and Missouri Botanical Garden Press, St. Louis, MO, 496 pp.

Wu, Z. Y., P. H. Raven and D. Y. Hong. 2007b. Flora of China. Vol. 12. Hippocastanaceae to Theaceae. Science Press, Beijing and Missouri Botanical Garden Press, St. Louis, MO, 534 pp.

Wu, Z. Y., P. H. Raven and D. Y. Hong. 2007c. Flora of China. Vol. 13. Clusiaceae to Araliaceae. Science Press, Beijing and Missouri Botanical Garden Press, St. Louis, MO, 548 pp.

Wu, Z. Y., P. H. Raven and D. Y. Hong. 2008. Flora of China. Vol. 7. Menispermaceae to Capparaceae. Science Press, Beijing and Missouri Botanical Garden Press, St. Louis, MO, 499 pp.
Wu, Z. Y., P. H. Raven and D. Y. Hong. 2010. Flora of China. Vol. 23. Acoraceae to Cyperaceae. Science Press, Beijing and Missouri Botanical Garden Press, St. Louis, MO, 461 pp.

Xu, X., V.-A. Funk, K. Li, J. Zhang, J. Wen and W. Zheng. 2018. Home at last III: Transferring Uechtritzia and Asian Gerbera species into Oreoseris (Compositae, Mutisieae). PhytoKeys 96: 1-19.

Xue, B., D.-P. Ye, Y.-Y. Shao and Y.-H. Tan. 2017. Polyalthia yingjiangensis sp. nov (Annonaceae) from the China/Myanmar border. Nordic Journal of Botany 35: 476-481.

Yamashita, J. and M.-N. Tamura. 2001. A new species of the genus Campylandra (Convallariaceae-Convallarieae) from Thailand. Blumea 46: 181-184.

Yan, K.-J., D.-X. Xu and Z.-Q. Song. 2016. Mycetia fangii (Rubiaceae), a new species from South China, with Notes on $M$. cauliflora. Systematic Botany 41: 229-237.

Yang, B., H.-B. Ding, S.-S. Zhou, X. Zhu, R. Li, M.-B. Maw and Y.H. Tan. 2018. Aristolochia sinoburmanica (Aristolochiaceae), a new species from north Myanmar. PhytoKeys 94: 13-22.

Yang, B., S.-S. Zhou, K.-W. Maung and Y.-H. Tan. 2017a. Reinwardtia glandulifera (Linaceae), a new species from Kachin State, northern Myanmar. Phytotaxa 316: 297-300.

Yang, B., S.-S. Zhou, K.-W. Maung and Y.-H. Tan. 2017b. Two new species of Impatiens (Balsaminaceae) from Putao, Kachin State, northern Myanmar. Phytotaxa 321: 103-113.

Yang, B., S.-S. Zhou, Q. Liu, K.-W. Maung, R. Li, R.-C. Quan and Y.-H. Tan. 2017c. Coelogyne magnifica (Orchidaceae), a new species from northern Myanmar. PhytoKeys 88: 109-117.

Yang, X., T.-N. Oo, S. Luo, A.-Z. Moe, G. Yao, J. Cai and Y. Wu. 2018. Taxonomic studies of Glochidion (Phyllanthaceae) from the Indo-China Peninsula (I): G. shanense, a new species from Myanmar. PhytoKeys 96: 57-62.

Yang, Z.-Z., S.-S. Zhou, Z.-H. Li, J. Wang, W.-H. Chen and Y.-M. Shui. 2015. Two new records of Begonia L. (Begoniaceae) from China. Plant Diversity and Resources 37: 425-427.

Yao, G., Y.-F. Deng and X.-J. Ge. 2015. A taxonomic revision of Pogostemon (Lamiaceae) from China. Phytotaxa 200: 1-67.

Yao, G., J. Gai, Y. Wu, X. Yang, T. N. Oo, A. Z. Moe and S. Luo. 2018. Taxonomic studies of Glochidion (Phyllanthaceae) from the Indo-China Peninsula (I): G. shanense, a new species from Myanmar. PhytoKeys 96: 57-62.

Yukawa, T., N. Tanaka and J. Murata. 2010. Doritis natmataungensis (Orchidaceae), a new species from Myanmar. Acta Phytotaxonomica et Geobotanica 60: 167-170.

Zhou, S.-S., Y.-H. Tan, X.-H. Jin, K. W. Maung, M. Zyaw, R. Li, R.-C. Quan and Q. Liu. 2018. Coelogyne victoria-reginae (Orchidaceae, Epidendroideae, Arethuseae), a new species from Chin State, Myanmar. PhytoKeys 98: 123-133. 